Postgate, J. R. (1953). J. gen. Microbiol. 9, 440-444.

\title{
On the Nutrition of Desulphovibrio desulphuricans: a Correction
}

\author{
By J. R. POSTGATE \\ Chemical Research Laboratory, Teddington, Middlesex
}

SUMMARY : High cell densities reached in cultures of Desulphovibrio desulphuricans (Hildenborough strain), grown in a medium of glucose, peptone, yeast extract and salts were due to the presence of a non-sulphate-reducing anaerobic contaminant whose presence was detectable only in special conditions. The relevance of this to previous studies on the Hildenborough strain is discussed and certain quantitative data are corrected.

Studies on the nutrition of a strain of Desulphovibrio desulphuricans (Postgate, $1951 a)$ appeared to indicate that a medium of glucose, salts, peptone and yeast extract permitted growth to about $750 \mu \mathrm{g}$. dry wt. cells $/ \mathrm{ml}$. Peptone and yeast extract acted synergistically; peptone was the more important constituent since, with high concentrations of peptone, yeast extract could be omitted, but the reverse was not true. Various pure vitamins, amino-acids, etc., were tested for their ability to replace the complex nitrogenous supplements, and a mixture of cysteine, serine, ornithine and isoleucine had some growth-promoting effect. Grossman \& Postgate (1953) showed that the cysteine in this mixture could be replaced by $\mathrm{Na}_{2} \mathrm{~S}$, indicating that the cysteine functioned through its reducing properties and not as a nutrient.

The present paper reports that the massive growth observed in the complex medium was partly due to the presence of an anaerobic contaminant in the stock strain used. The contaminant was only detectable in special conditions.

\section{METHODS}

Organism. A strain of $D$. desulphuricans called 'Hildenborough' was used throughout; its origin, maintenance and methods of subculture have been described (Postgate, 1951 a). A stock was kept in a lyophilized condition, prepared by the procedure described in Chemistry Research (1951).

Media. Medium A consisted of glucose, peptone, yeast extract and sulphates (Postgate, 1951a); medium B consisted principally of sodium lactate, yeast extract and sulphates (Butlin, Adams \& Thomas, 1949). When necessary, either medium was supplemented with one or more of the following: $(a)$ agar (British Drug Houses Ltd.), $15 \mathrm{~g}$./l. for solid media; (b) $\mathrm{FeSO}_{4} \cdot\left(\mathrm{NH}_{4}\right)_{2} \mathrm{SO}_{4} \cdot 6 \mathrm{H}_{2} \mathrm{O}$ (0.5 g./l.) when it was desired to detect sulphate-reducing bacteria by blackening due to formation of $\mathrm{FeS}$; (c) freshly sterilized and neutralized L-cysteine hydrochloride $\left(5 \times 10^{-3} \mathrm{M}\right.$; British Drug Houses Ltd.) when it was desired that all viable organisms should grow (Chemistry Research, 1951; Grossman \& Postgate, 1953). Reagents were of 'analytical reagent' grade except where stated. 
Rough agar dilutions. A sealed Pasteur pipette was dipped into the culture being tested, and then dipped successively into seven soft-glass test tubes $\left(15 \times 1 \mathrm{~cm}\right.$.) each containing c. $4 \mathrm{ml}$. molten agar medium $\left(40 \pm 1^{\circ}\right)$, supplemented with $\mathrm{FeSO}_{4} \cdot\left(\mathrm{NH}_{4}\right)_{2} \mathrm{SO}_{4} \cdot 6 \mathrm{H}_{2} \mathrm{O}$. The medium was allowed to set and incubated in air at $30^{\circ}$. This procedure enabled populations to be checked rapidly for anaerobic contaminants, and gave well-separated black colonies of sulphate-reducing bacteria suitable for isolation in the third or fourth dilution. When the medium was supplemented with cysteine well-separated colonies appeared in the sixth or seventh dilution.

\section{RESULTS}

A stock of the Hildenborough strain maintained in medium A, which regularly reached high cell densities on subculture, appeared pure when plated out for aerobic and anaerobic contaminants on (1) medium A solidified with agar, (2) medium B solidified with agar, (3) blood agar, (4) glucose peptone agar. On testing by the agar dilution procedure in medium $\mathbf{A}$ solidified with agar and containing $\mathrm{FeSO}_{4} \cdot\left(\mathrm{NH}_{4}\right)_{2} \mathrm{SO}_{4} \cdot 6 \mathrm{H}_{2} \mathrm{O}$ white colonies were sometimes observed among the black. The white colonies consisted of Gram-negative non-motile rods. Re-isolation of sulphate-reducing bacteria from the black colonies yielded a strain giving only limited growth in medium A; growth was restored to its former level when a culture derived from a white colony was added. Some properties of the purified and mixed strains are reported below.

The pure Hildenborough strain of $D$. desulphuricans consisted of typical motile vibrios with no tendency to pleomorphism. Growth in medium A reached a maximum of $c .350 \mu \mathrm{g}$. dry wt. cells/ml., but was nevertheless superior to growth in medium B (c. $100 \mu \mathrm{g} . / \mathrm{ml}$.). The cell density in medium A was increased by greater amounts of glucose and sulphate, a maximum of $500 \mu \mathrm{g} . / \mathrm{ml}$. being reached with glucose $(80 \mu \mathrm{mol} . / \mathrm{ml}$. $)+\mathrm{Na}_{2} \mathrm{SO}_{4}(40 \mu \mathrm{mol} . / \mathrm{ml}$. $)$. The cell density was not increased by culture in medium $\mathbf{A}$ in which the contaminant had been grown and filtered off. Growth of the purified strain in medium A without peptone and yeast extract was stimulated by a mixture of cysteine, serine, ornithine and isoleucine to the same extent as reported for the impure strain.

The hydrogenase activity of the pure strain was greater than the reported hydrogenase activity of the mixed strains; cell suspensions reduced sulphate in hydrogen with $-Q_{\mathrm{H}}$, values of $c .700 \mathrm{~mm} .{ }^{3} \mathrm{H}_{2} / \mathrm{mg}$. dry wt./hr., compared with values of $c .200$ for the mixed strain. Sulphite, thiosulphate and tetrathionate were also reduced; thiosulphate and tetrathionate were attacked more slowly than sulphate or sulphite as reported for the mixed strains (Postgate, $1951 b)$.

The contaminant was an obligate anaerobic, Gram-negative, non-motile rod, often paired, which formed round or disk-shaped colonies with a perceptible yellowish tint in medium $\mathrm{A}$ agar $+\mathrm{FeSO}_{4}\left(\mathrm{NH}_{4}\right)_{2} \mathrm{SO}_{4} \cdot 6 \mathrm{H}_{2} \mathrm{O}$. It grew very feebly in liquid medium $A$ and frequently died out on subculture; growth was improved by addition of the filtrate of a pure culture of Hildenborough grown in medium A. These observations suggest that there was some nutri- 
tional interdependence between the contaminant and the sulphate-reducing bacteria. The cell densities reached in medium $A$ were too low to be measured accurately in a photo-electric turbidimeter; they were of the order of $30 \mu \mathrm{g}$. dry wt./ml. The organism did not grow in medium $\mathbf{B}$.

Table 1. Growth of purified and contaminated Desulphovibrio desulphuricans (Hildenborough) in various media

Cultures were incubated until growth had ceased and the cell densities were determined photometrically.

Medium
A
A
A
A
B
B
A $^{*}$

\begin{tabular}{|c|c|}
\hline Strain & $\begin{array}{l}\text { Maximum ce } \\
\text { ( } \mu \mathrm{g} . \text { dry wt. }\end{array}$ \\
\hline Impure Hildenborough & \\
\hline Purified Hildenborough & 270 \\
\hline Contaminant & c. \\
\hline Purified Hildenborough + contaminant & \\
\hline Purified Hildenborough & \\
\hline Purified Hildenborough + contaminant & \\
\hline Contaminant & \\
\hline
\end{tabular}

* Medium A in which Hildenborough had been grown and filtered off.

The mixed strains (Postgate, 1951 $a$ ) consisted wholly of Gram-negative organisms which appeared as a mixture of motile vibrios, non-motile rods and intermediate forms. The apparent proportion of rods to vibrios varied during growth, vibrios predominating in the stationary phase. The rods were often elongated and bent, and sometimes paired. This heteromorphic appearance was originally attributed to pleomorphism, since plate tests did not indicate any contaminants, but it is now clear that at least some of the rodforms were contaminants. Cultures in medium A reached about $750 \mu \mathrm{g}$. dry wt. cells/ml., but cultures in medium $B$ only reached cell densities similar to the pure strain in medium B. Moreover, cultures of the mixed strain in medium $B$ appeared to consist wholly of vibrios; few, if any, rod forms could be seen. Nevertheless, even after many subcultures in medium B, the contaminant re-appeared immediately on subculture into medium $\mathbf{A}$. The contaminant was also found by this procedure in a stock that had been maintained in Baars's (1930) medium for many years.

Other strains. Two other stock strains of $D$. desulphuricans out of six so far tested were found to be contaminated with an organism similar to that found with Hildenborough. Like Hildenborough, these strains had been checked by plating for aerobic and anaerobic contaminants at the time of their isolation or receipt. The El Agheila Z strain, which has been the subject of communications from this laboratory (Adams, Butlin, Hollands \& Postgate, 1951; Postgate, $1952 b, c)$ was pure.

\section{DISCUSSION}

The heteromorphic appearance of the Hildenborough strain was originally regarded as 'typical', and was attributed to the pleomorphism for which the genus Desulphovibrio is notable. In fact its 'pleomorphism' was due to the presence of a contaminant which was detectable culturally only in the special conditions described. The contaminant, like those described by Bunker (1939), 
stimulated growth of the sulphate-reducing bacteria in medium $\mathbf{A}$, and its own growth in this medium was improved by sulphate-reducing bacteria. Moreover, though it did not grow alone in medium $B$, it nevertheless survived many subcultures in this medium provided sulphate-reducing bacteria were present. Clearly there was an effective syntrophism between the two bacteria; this made detection of the contaminant difficult.

In view of the presence of a contaminant in the Hildenborough strain of $D$. desulphuricans, certain quantitative data previously reported require correction. Fortunately the qualitative information given is unaffected.

The cell densities reached in medium $\mathbf{A}$ by $D$. desulphuricans, strain Hildenborough, are not as great as originally reported (Postgate, 1951 $a$ ), but are nevertheless greater than in medium B. The growth-promoting effect of a mixture of cysteine, serine, ornithine and isoleucine is confirmed with the purified strain. This paper reported that, on one occasion, the Hildenborough strain suddenly lost its ability to give massive growth after more than ninety passages in medium $\mathbf{A}$. This variation was not attributable to any change in the medium, cultural conditions or morphology of the strain; a new series from a stock in Baars's (1930) medium behaved 'normally'. In the light of the present observations it seems likely that the strain was inadvertently purified on this occasion, but that the consequent change to a more regular morphological appearance was overlooked. A return to the stock in Baars's medium gave the mixed population again.

A further paper (Postgate, 1951 b) was concerned with the reduction of sulphur compounds by cell suspensions in hydrogen. Its general conclusions remain valid since the contaminant did not have hydrogenase activity, but, owing to dilution by contaminant, the specific activities of the sulphatereducing bacteria in cell suspensions used were presumably greater than those quoted. The relative rates of attack of substrates by the pure strain were the same as with mixed population. Errors in growth experiments introduced by the presence of the contaminant cannot have been great or they would have been noticed in the appropriate controls.

Inhibition of growth and of hydrogen absorption by various sulphate analogues and other inhibitors was described, and the nature of the inhibitions studied (Postgate, 1949, 1952a). The conclusions reached in these papers remain valid, except that the specific cell activities reported in studies with suspensions were probably too low owing to dilution by the contaminant.

Postgate (1952 c), Grossman \& Postgate (1953), in the section entitled ' Fundamental studies of sulphate-reducing bacteria' in Chemistry Research 1952 and publications subsequent to these, referred to the purified strain. Earlier issues of Chemistry Research described work with the impure strain, though many of these studies used media in which the effect of the contaminant would be negligible.

The author is indebted to Dr J. Senez for introducing him to the procedure described as 'rough agar dilutions'. This paper is published by permission of the Director, Chemical Research Laboratory. 


\section{REFERENCES}

Adams, M. E., Butun, K. R., Hollands, S. J. \& Postgate, J. R. (1951). The rôle of hydrogenase in the autotrophy of Desulphovibrio. Research, Lond. 4, 245.

BaAns, J. K. (1930). Over sulphaatreductie door bacterien, Dissertation, Delft.

BUNKER, H. J. (1939). Factors influencing the growth of Vibrio desulphuricans. Int. Congr. Microbiol. (New York, 1939), p. 64.

Butlin, K. R., Adams, M. E. \& Thomas, M. (1949). The isolation and cultivation of sulphate-reducing bacteria. J. gen. Microbiol. 3, 46.

Chemistry Research 1952 and earlier issues. London: H.M. Stationery Office.

Grossman, J. P. \& Postante, J. R. (1953). The cultivation of sulphate-reducing bacteria. Nature, Lond. 171, 600.

Postgate, J. R. (1949). Inhibition of sulphate reduction by selenate. Nature, Lond. 164, 670.

Postate, J. R. (1951 a). On the nutrition of Desulphovibrio desulphuricans. J. gen. Microbiol. 5, 714.

Postgate, J. R. (1951 b). The reduction of sulphur compounds by Desulphovibrio desulphuricans. J. gen. Microbiol. 5, 725.

Postgate, J. R. (1952a). Competitive and non-competitive inhibitors of bacterial sulphate reduction. J. gen. Microbiol. 6, 128.

Postgate, J. R. (1952b). Growth of sulphate-reducing bacteria in sulphate-free media. Research, Lond. 5, 189.

Postgate, J. R. (1952c). The metabolism of pyruvate by sulphate reducers. Int. Congr. Biochem. (Paris, 1952), p. 92.

(Received 19 May 1953) 